\title{
Carbon biogeochemistry of the Betsiboka estuary (north-western Madagascar)
}

\author{
Olivier Harifidy Ralison ${ }^{\mathrm{a}, 1}$, Alberto Vieira Borges ${ }^{\mathrm{b}}$, Frank Dehairs ${ }^{\mathrm{a}}$, J.J. Middelburg ${ }^{\mathrm{c}}$, \\ Steven Bouillon ${ }^{\mathrm{a}, \mathrm{c}, \mathrm{d}, *}$
}

${ }^{a}$ Vrije Universiteit Brussel, Department of Analytical and Environmental Chemistry, Pleinlaan 2, B-1050 Brussels, Belgium

${ }^{\mathrm{b}}$ Université de Liège, Chemical Oceanography Unit, Institut de Physique (B5), B-4000 Liège, Belgium

${ }^{\mathrm{c}}$ Netherlands Institute of Ecology, Centre for Estuarine and Marine Ecology (NIOO-KNAW), Yerseke, The Netherlands

${ }^{\mathrm{d}}$ Katholieke Universiteit Leuven, Department of Earth and Environmental Sciences, Kasteelpark Arenberg 20, B-3001 Leuven, Belgium

\section{A R T I C L E I N F O}

\section{Article history:}

Received 17 September 2007

Received in revised form 17 January 2008

Accepted 18 January 2008

Available online 5 February 2008

\begin{abstract}
A B S T R A C T
Madagascar's largest estuary (Betsiboka) was sampled along the salinity gradient during the dry season to document the distribution and sources of particulate and dissolved organic carbon (POC, DOC) as well as dissolved inorganic carbon (DIC). The Betsiboka was characterized by a relatively high suspended matter load, and in line with this, low $\mathrm{DOC} / \mathrm{POC}$ ratios $(\sim 0.4-2.5)$. The partial pressure of $\mathrm{CO}_{2}\left(\mathrm{pCO}_{2}\right)$ was generally above atmospheric equilibrium (270-1530 ppm), but relatively low in comparison to other tropical and subtropical estuaries, resulting in low average $\mathrm{CO}_{2}$ emission to the atmosphere $\left(9.1 \pm 14.2 \mathrm{mmol} \mathrm{m}^{-2} \mathrm{~d}^{-1}\right)$. Despite the fact that $\mathrm{C} 4$ vegetation is reported to cover $>80 \%$ of the catchment area, stable isotope data on DOC and POC suggest that C4 derived material comprises only $\sim 30 \%$ of both pools in the freshwater zone, increasing to $\sim 60-70 \%$ and $50-60 \%$, respectively, in the oligohaline zone due to additional lateral inputs. Sediments from intertidal mangroves in the estuary showed low organic carbon concentrations $(<1 \%)$ and $\delta^{13} \mathrm{C}$ values (average $-19.8 \%$ ) consistent with important inputs of riverine imported C4 material. This contribution was reflected in $\delta^{13} \mathrm{C}$ signatures of bacterial phospholipid derived fatty acids $(i+a 15: 0)$, suggesting the potential importance of terrestrial organic matter sources for mineralization and secondary production in coastal ecosystems.
\end{abstract}

() 2008 Elsevier Ltd. All rights reserved.

\section{Introduction}

Rivers and estuaries are highly active areas in terms of organic matter and nutrient processing, where riverine transported organic matter can undergo significant biogeochemical modifications (e.g., Aufdenkampe et al., 2007; Cole et al., 2007). Despite the high riverine organic matter flux in the tropics (Ludwig et al., 1996a,b; Schlünz and

\footnotetext{
* Corresponding author. Address: Katholieke Universiteit Leuven, Department of Earth and Environmental Sciences, Kasteelpavk Arenberg 20, B-3001 Leuven, Belgium, Fax: +32 16321997.

E-mail address: steven.bouillon@ees.kuleuven.be (S. Bouillon).

1 Present address: WWF Madagascar and West Indian Ocean Programme Office, B.P. 738, Antananarivo, Madagascar.
}

Schneider, 2000), data on the biogeochemistry and nutrient cycling in tropical estuaries are still scarce in comparison to the temperate zone, and to the best of our knowledge, no biogeochemical studies on Madagascan estuaries exist. Recent data from east African estuaries (Bouillon et al., 2007a,b) suggest that fluxes of particulate organic carbon (POC) could be much higher than predicted by empirical models of riverine carbon transport for this zone (Ludwig et al., 1996b), and that inorganic carbon export might be higher than POC export, again in contrast to model predictions. While a number of datasets are available on the origin of POC in tropical rivers and estuaries, much less is known on the composition and origin of dissolved organic carbon (DOC) and its relation to POC. Particulate and dissolved pools of organic matter are often 
compositionally distinct, and experimental studies indicate that preferential sorption of nitrogen rich compounds are at least partially responsible for such differences (Aufdenkampe et al., 2001 and references therein). Moreover, during riverine transport and retention in estuaries, repartitioning of organic matter between dissolved and particulate organic matter pools may take place, with total suspended matter loads playing a critical factor in the overall partitioning (Middelburg and Herman, 2007).

Many of the larger east African river systems drain catchment areas where the vegetation consists of plants using C3 and C4 photosynthetic pathways, with a variable relative contribution in the overall land cover. In the more arid regions, $\mathrm{C} 3$ vegetation is often concentrated along rivers as floodplain or fringing forests. These systems therefore offer an ideal opportunity to study the effects of landscape scale vegetation patterns on riverine carbon pools and possible differential biogeochemical processing of C3 and C4 derived organic matter. Earlier studies suggest that the composition of the dominant vegetation is indeed a major determinant of riverine organic matter composition (Bird et al., 1994; Martinelli et al., 1999; Coynel et al., 2005), and that recent land use changes (i.e., over the last few decades) can be rapidly reflected in riverine organic matter composition (Bernardes et al., 2004). Recent data from tropical estuaries with significant $C 4$ vegetation in the catchment areas further suggest that dissolved and particulate organic carbon pools can have variable relative contributions of different organic matter sources, and that C3 and C4 derived organic matter undergo different degrees of processing in the estuarine zone (e.g. Bianchi et al., 2004; Bouillon et al., 2007a). However, data from a range of estuaries are needed in order to generalize whether the reactivity of $\mathrm{C} 3$ and $\mathrm{C} 4$ derived organic matter is consistently different across different estuaries, and which implications this might have for the characteristics of the organic matter transported to the coastal zone in such systems. Mineralization of organic matter and its subsequent efflux as $\mathrm{CO}_{2}$ to the atmosphere has recently been shown to be an important link in coastal carbon budgets, and represents a significant but previously underestimated direct bypass of $\mathrm{CO}_{2}$ to the atmosphere in the global carbon budget (Borges, 2005). Given the lack of such data from tropical estuaries, field data from a variety of tropical systems are needed to better constrain fluxes and cycling of carbon in these systems.

In this study, we report data on the basic physico-chemical properties, organic and inorganic carbon pools and their stable isotope composition along the salinity gradient of the Betsiboka estuary (Madagascar), in order to present a first description of the biogeochemical characteristics of Malagasy estuaries. The Betsiboka is the main river of Madagascar in terms of length, basin area, as well as discharge (Berthois and Crosnier, 1965). Although there is ongoing discussion on the extent of original forest cover in the highlands of Madagascar (see e.g. Klein, 2002; Vägen et al., 2007 and references therein), it is clear that intensive deforestation has taken place in the catchment area, and that this has resulted in a very high erosion rate. During the rainy season, red lateritic soil is eroded and transported from the highlands ("Hauts plateaux") by tributaries towards the estuary, and finally ends up in the Mozambican Channel. The Betsiboka estuary has therefore evolved to a high sedimentation zone and is characterised by one of the world's fastest coastal dynamics (Lebigre, 1990). Drainage basins with steep elevation gradients and high erosion rates can be disproportionately important in sediment and organic carbon delivery to the ocean, i.e., provide higher inputs of sediment and organic carbon per unit of surface area than other types of drainage basins, as has been shown for islands in the southwestern Pacific Ocean (Milliman, 1995; Lyons et al., 2002).

\section{Materials and methods}

\subsection{Study area}

The Betsiboka (Fig. 1) is the main river system in Madagascar, draining an area of $\sim 49,000 \mathrm{~km}^{2}$ in the northwestern part of the island (Randrianarijaona, 1983; Paulian, 1984). The Betsiboka River has its source in the Angavo cliffs, north of Antananarivo at an altitude of $1755 \mathrm{~m}$. Major tributaries are Mahajamba, Isandrano and Ikopa rivers. Vanden Bossche and Bernacsek (1990) estimated its total length at about $525 \mathrm{~km}$, and the discharge rate is reported to be in the order of $271 \mathrm{~m}^{3} \mathrm{~s}^{-1}$ (i.e., $35 \mathrm{~km}^{3} \mathrm{y}^{-1}$, Vorosmarty et al., 1998). The Betsiboka discharges in the Mozambican channel near the town of Mahajanga, in the Boina region. The external part of its mouth called Bombetoka Bay is situated at $15^{\circ} 5^{\prime} \mathrm{S}$ and $46^{\circ} 18^{\prime} \mathrm{E}$. The large size of the drainage basin associated with huge discharge (Berthois and Crosnier, 1965) causes important settling of sediment within the estuary, ranging from $15 \times 10^{6}$ to $50 \times 10^{6} \mathrm{t} \mathrm{y}^{-1}$ (Randrianarijaona, 1983; Paulian, 1984; Ritter, 1986). The destruction of the original forests during the last 50 years intensified erosion, with erosion rates in the highlands in the order of 25-250 tha $\mathrm{t}^{-1} \mathrm{y}^{-1}$ (Randrianarijaona, 1983). Furthermore, various anthropogenic factors are likely to influence the ecology and biogeochemistry of the estuary: new developments have been constructed behind the mangrove forest which faces the Bombetoka Bay. Shrimp aquaculture ponds have been implanted in the area since 1999 and at the time of sampling covered an area of $\sim 200$ ha. Mangroves are an important component of the estuary and cover approximately 46,000 ha. The climate is characterised by the alternation of a warm and wet season from November to April, and a well-marked dry and cool season from May to October. The sampling was conducted at the end of the dry season, when the Betsiboka was at its lowest level of discharge. The tidal regime is semi-diurnal, with an average tidal amplitude of $3.5 \mathrm{~m}$.

\subsection{Sampling and analytical techniques}

Water samples were collected along the salinity gradient in the main estuary, and in a few bordering tidal mangrove creeks (Fig. 1) in October 2005 (dry season). Surface water for field measurements of dissolved $\mathrm{O}_{2}, \mathrm{pH}$, temperature and salinity were taken with a Niskin bottle $\sim 0.5 \mathrm{~m}$ below the surface. Oxygen saturation level $\left(\% \mathrm{O}_{2}\right)$ was measured immediately after collection with a polarographic electrode (WTW Oxi-340) calibrated on saturated air, with an accu- 
A

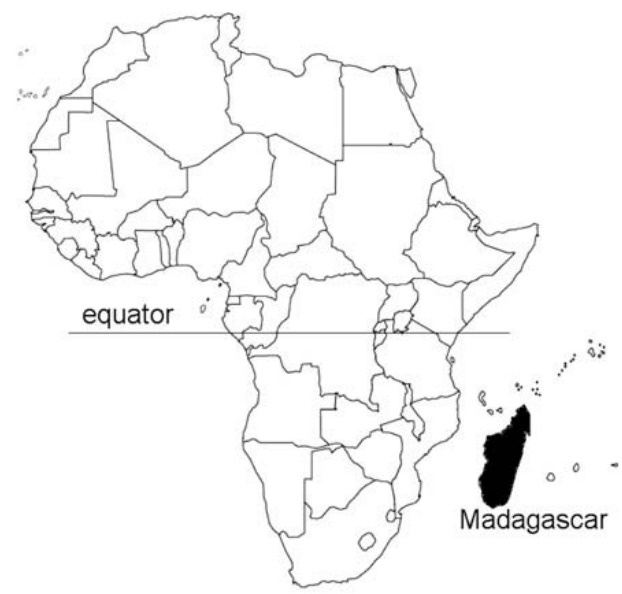

B

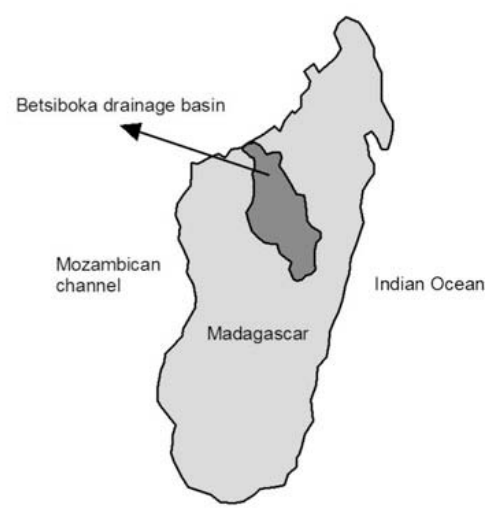

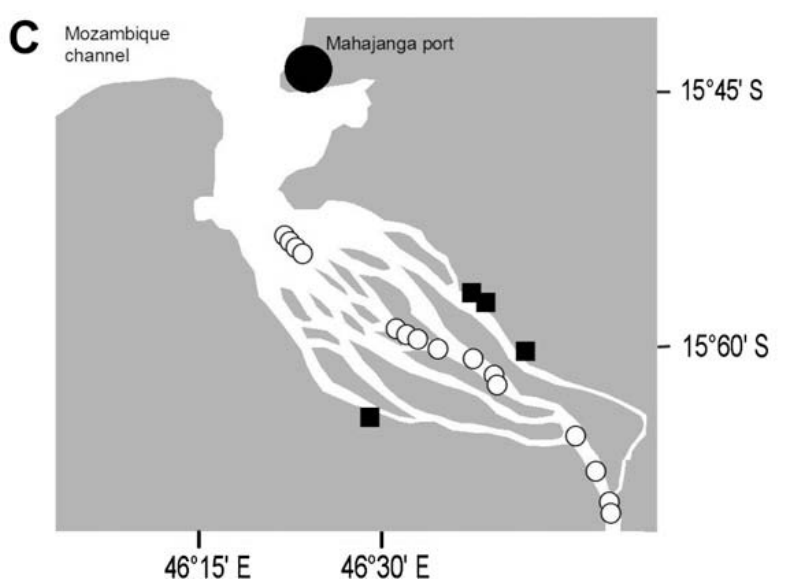

Fig. 1. (A) Position of Madagascar in relation to the African continent, (B) localisation of the Betsiboka drainage basin within Madagascar, and (C) detailed map of the Bestiboka estuary. Sampling stations along the salinity gradient for water column measurements are indicated by open circles, and mangrove sites where surface sediments were taken are indicated by black squares.

racy of $\pm 1 \%$. pH was measured using a Ross type combination electrode (ORION) calibrated on the NBS (US National Bureau of Standards) scale, as described by Frankignoulle and Borges (2001), with a reproducibility of $\pm 0.01 \mathrm{pH}$ units. Wind speed was measured in the field with a hand-held anemometer. Samples for total suspended matter (TSM) were taken by collecting a known volume of surface water (300-1000 ml), which was passed through pre-combusted $\left(12 \mathrm{~h}\right.$ at $\left.450{ }^{\circ} \mathrm{C}\right)$ and pre-weighed $47 \mathrm{~mm}$ diameter glass fibre filters (Whatman GF/F). Subsequently, the filters were dried at $60^{\circ} \mathrm{C}$ for $12 \mathrm{~h}$ prior to packing in Petri dishes.

Samples for the analysis of carbon stable isotope ratios of dissolved inorganic carbon $\left(\delta^{13} C_{\text {DIC }}\right)$ were taken from the same Niskin bottle by gently overfilling $12 \mathrm{ml}$ glass headspace vials, poisoned by addition of $20 \mu \mathrm{l}$ of a saturated $\mathrm{HgCl}_{2}$ solution, and closing tightly with a septum lined screw cap. $\delta^{13} \mathrm{C}_{\text {DIC }}$ was measured as described in Gillikin and Bouillon (2007). Samples for the determination of total alkalinity (TA) were obtained by pre-filtering $100 \mathrm{ml}$ of water through pre-combusted Whatman GF/F filters, subsequent filtration through $0.2 \mu \mathrm{m}$ cellulose acetate syringe filters, and stored in HDPE bottles until analysis. TA was determined by automated titration with $0.01 \mathrm{M} \mathrm{HCl}$. The $\mathrm{pCO}_{2}$ and DIC concentrations were computed from $\mathrm{pH}$ and TA measurements using the thermodynamic constants described in Frankignoulle and Borges (2001), with an accuracy of computed DIC and $\mathrm{pCO}_{2}$ values estimated at $\pm 5 \mu \mathrm{mol} \mathrm{kg}{ }^{-1}$ and better than $\pm 2 \%$, respectively. The exchange flux of $\mathrm{CO}_{2}\left(F, \mathrm{mmol} \mathrm{m}^{-2} \mathrm{~s}^{-1}\right.$ and converted to units of $\mathrm{mmol} \mathrm{m}^{-2} \mathrm{~d}^{-1}$ ) across the water-air interface was calculated according to $F=k \alpha \Delta \mathrm{pCO}_{2}$ where $k$ is the gas transfer velocity $\left(\mathrm{m} \mathrm{s}^{-1}\right)$, athe solubility coefficient for $\mathrm{CO}_{2}\left(\mathrm{~mol} \mathrm{~m}^{-3} \mathrm{~atm}^{-1}\right)$, and $\Delta \mathrm{pCO}_{2}$ (atm) represents the difference in pCO2 between water and air (see Liss and Slater, 1974). For consistency with previous studies in tropical estuaries and mangrove creeks, we used the $k$-wind parameterization proposed by Raymond and Cole (2001) for estuarine environments.

Samples for DOC and $\delta^{13} \mathrm{C}_{\mathrm{DOC}}$ were prepared similar to those for TA, but poisoned with $50 \mu \mathrm{l}$ of $\mathrm{H}_{3} \mathrm{PO}_{4}$, and stored in glass vials $(40 \mathrm{ml})$ with a Teflon lined septum and screw cap. DOC concentrations and $\delta^{13} \mathrm{C}$ signatures were determined using a modified Thermo HiperTOC interfaced to a Thermo Delta + XL IRMS (Bouillon et al., 2006). Although (pre)filtration on glass fibre filters may result in a certain degree of sorption of DOC to the filter, this effect is likely to be minimal (Kaplan, 1994) and glass fibre filters are therefore commonly used for sample filtration or pre-filtration for DOC analysis (e.g., Abril et al., 2002; Sharp et al., 2002). Samples for determination of Chlorophyll a (hereafter Chl $a$ ) were obtained by filtering a known volume of surface water on pre-combusted $47 \mathrm{~mm} \mathrm{GF/F} \mathrm{filters.} \mathrm{These} \mathrm{were} \mathrm{stored} \mathrm{in} \mathrm{a}$ 
screw cap vial, placed in a cool box with ice, and stored frozen until later analysis. Pigments were extracted for approximately $12 \mathrm{~h}$ in $15 \mathrm{ml}$ of $90 \%$ acetone at $4{ }^{\circ} \mathrm{C}$ and analyzed with a Turner TD-700 Fluorimeter. The accuracy of Chl $a$ analysis was estimated to be $\pm 4 \%$. Samples for determination of POC and $\delta^{13} \mathrm{C}_{\mathrm{POC}}$ were filtered on $25 \mathrm{~mm} \mathrm{GF} / \mathrm{F}$ filters (pre-combusted at $450{ }^{\circ} \mathrm{C}$ for $4 \mathrm{~h}$ ), dried at $60{ }^{\circ} \mathrm{C}$ overnight, and stored in Petri slides. These were later decarbonated under $\mathrm{HCl}$ fumes, re-dried and packed in Ag cups. POC, POC/PN ratios and $\delta{ }^{13} C_{\text {Poc }}$ were determined on a Flash 1112 elemental analyzer coupled to a Thermo Delta + XL IRMS. $\delta^{15} \mathrm{~N}$ values of particulate nitrogen (PN) were determined on subsamples of the $47 \mathrm{~mm} \mathrm{GF} / \mathrm{F}$ filters used for TSM determination, wrapped in Ag cups, and analyzed on the abovementioned EA-IRMS setup.

It should be noted that due to either sampling errors or analytical problems, some stations have missing data for some parameters, so that the number of data reported in the figures does not always correspond to the number of sampling stations indicated on Fig. 1.

Intertidal mangrove sediments were sampled in different stations in the estuarine zone, for determination of $\% \mathrm{OC}$, and $\delta^{13} \mathrm{C}$ signatures of bulk sediment organic matter and bacteria specific PLFA (phospholipid fatty acids). Sediment cores were collected with a $3.8 \mathrm{~cm}$ diameter Plexiglas corer, and sliced into $0-1,1-2,2-4$ and $4-10 \mathrm{~cm}$ sections. These were stored frozen, transported back to the home lab on dry ice, and freeze dried. Samples for \%C and $\delta^{13} \mathrm{C}$ of bulk sediment organic carbon were acidified with $1 \mathrm{M}$ $\mathrm{HCl}$ in silver cups to remove carbonates, and analyzed on a Thermo Flash EA1112 - Delta + XL setup. Extraction, derivatization, and $\delta^{13} \mathrm{C}$ analysis of bacterial PLFA was performed as described in Bouillon and Boschker (2006).
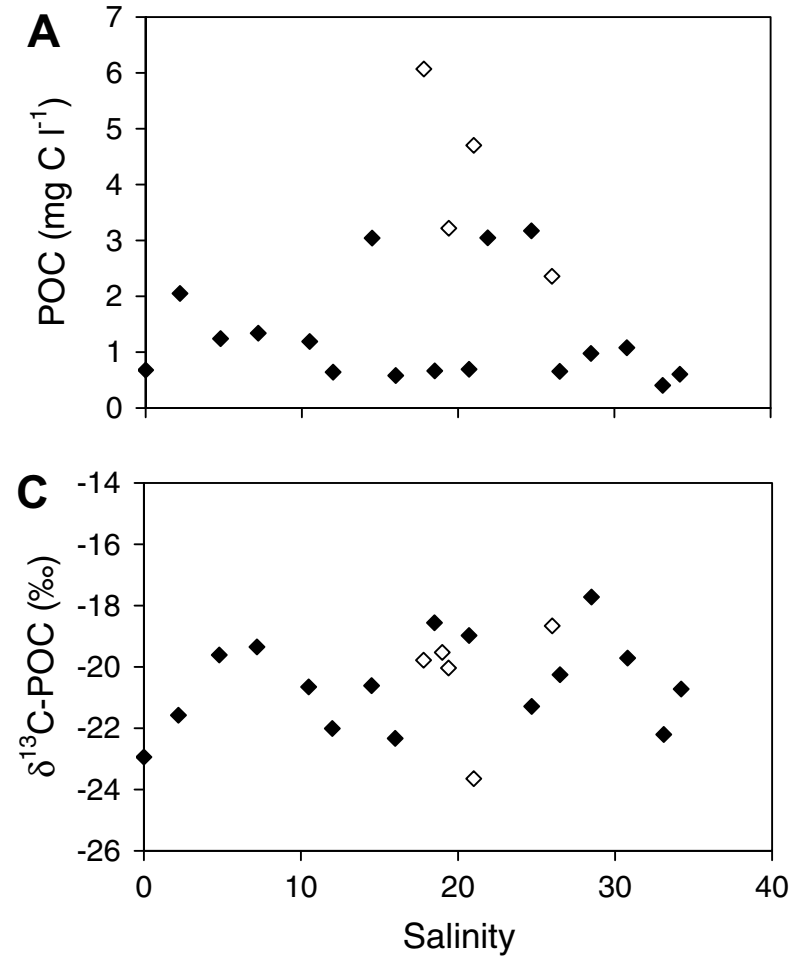

\section{Results}

The salinity along the Betsiboka main estuary ranged between 0 and 32.4, while the tidal mangrove creeks had brackish salinities between 19 and 26. TSM concentrations generally ranged between 30 and $100 \mathrm{mg} \mathrm{l}^{-1}$ in the estuary, with two higher values recorded at salinities 14.5 and 33.1 (148 and $286 \mathrm{mg} \mathrm{l}^{-1}$, respectively). TSM concentrations in the tidal creeks were highly erratic, ranging between 60 and $849 \mathrm{mg} \mathrm{l}^{-1}$ (data not shown).

POC concentrations generally ranged between 0.5 and $2.0 \mathrm{mg} \mathrm{Cl}^{-1}$ in the main estuary, with some values $\sim 3 \mathrm{mg} \mathrm{Cl}^{-1}$ in the meso- and polyhaline zone (Fig. 2A). In the tidal creeks, POC values were distinctly higher and ranged between 2.3 and $6.1 \mathrm{mg} \mathrm{Cl}^{-1}$ (Fig. 2A). Concentrations of DOC were in the order of $0.5 \mathrm{mg} \mathrm{l}^{-1}$ in the freshwater and marine end members, but showed a clear non-conservative pattern with highest values in the mesohaline part of the estuary (up to $\sim 1.5 \mathrm{mg} \mathrm{Cl}^{-1}$ ), and also relatively high DOC levels in the tidal creeks (0.9$1.4 \mathrm{mg} \mathrm{Cl}^{-1}$, Fig. 2B). Stable isotope signatures of DOC and POC ranged between $-23.7 \%$ and $-17.7 \%$, and between $-23.6 \%$ and $-16.9 \%$, respectively (Fig. $2 \mathrm{C}$ and D). In the POC pool, the estuarine gradient in $\delta^{13} \mathrm{C}$ was somewhat erratic, with no clear pattern observed, and similar values in the tidal mangrove creeks (Fig. 2C). For DOC, however, there is a clear pattern of more ${ }^{13} \mathrm{C}$ enriched values in the mesohaline part of the estuary (Fig. 2D) coinciding with the net inputs of DOC in this zone (Fig. 2B), and relatively ${ }^{13} \mathrm{C}$ depleted $\mathrm{DOC}$ in the tidal mangrove creeks (Fig. 2D). DOC/POC ratios ranged between 0.26 and 2.45 in the estuary, and were $\sim 0.4$ in the tidal creeks (only 2 data points for the latter). Lowest values were associated
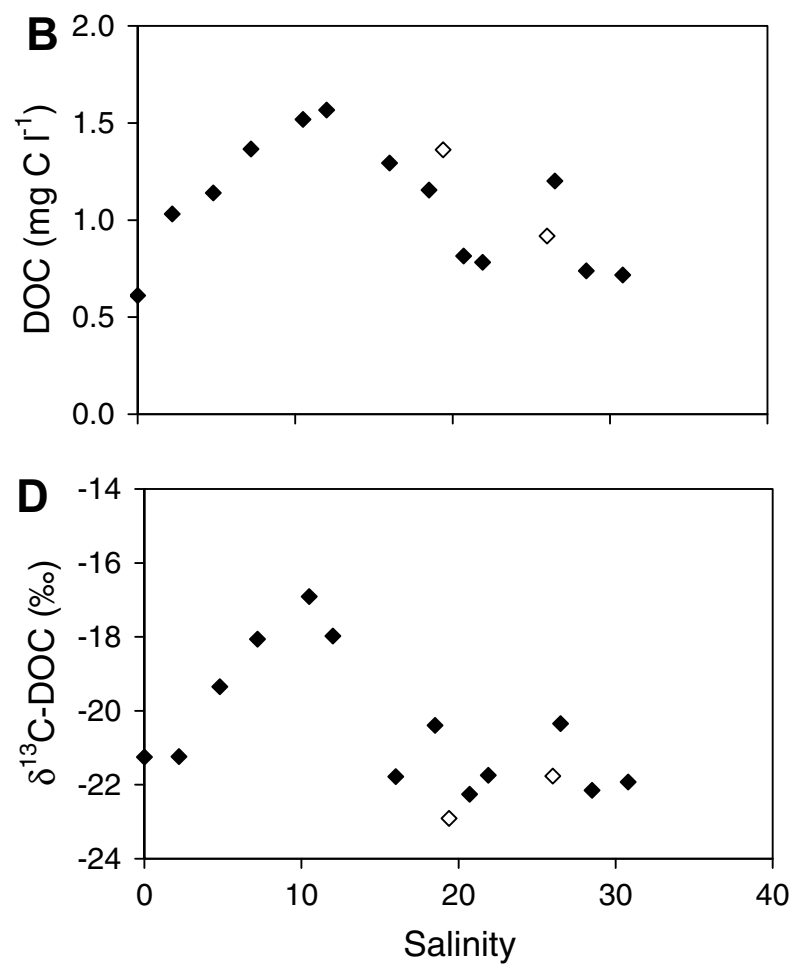

Fig. 2. Distribution and carbon isotope composition of organic carbon pools along the Betsiboka estuary (black diamonds) and tidal mangrove creeks (open diamonds): (A) POC, (B) DOC, (C) $\delta^{13} C_{\text {POC }}$, and (D) $\delta^{13} C_{\text {DOC. }}$ 
with higher levels of TSM, and the DOC/POC ratios observed in the Betsiboka are in the lower range of values reported for estuarine and coastal systems in the Western Indian Ocean region (Fig. 3 ).

Chl $a$ concentrations were generally low in the estuary proper $\left(0.9-7.2 \mu \mathrm{g} \mathrm{l}^{-1}\right)$, but distinctly higher in some of the tidal creeks where values between 15 and $25 \mu \mathrm{g} \mathrm{l} \mathrm{l}^{-1}$ were recorded (Fig. 4). POC/Chl $a$ ratios ranged overall between 172 and 836, and were generally high in both the estuary proper $(388 \pm 194, n=17)$ and the tidal creeks (587 $\pm 276, n=5)$, indicating that the POC pool is dominated by detrital organic matter.

In the freshwater part of the estuary, $\delta^{15} \mathrm{~N}$ of PN was relatively high $(+9.1 \%$ ), and increased further in the mesohaline part of the estuary, reaching values as high as $+19.8 \%$ (Fig. 5). At salinity $>12$, however, $\delta^{15} \mathrm{~N}$ values dropped markedly and ranged between $-3.6 \%$ and $5.8 \%$, with data from the tidal creeks falling within this range (Fig. 5).

Along the salinity gradient, little variation in $\% \mathrm{O}_{2}$ levels was observed, with a slight oversaturation on average (107 $\pm 8 \%$, Fig. 6A). The tidal creeks, in contrast, were generally undersaturated (74-94\%), with one unusually high exception (238\%, Fig. $6 \mathrm{~A}) \cdot \mathrm{pCO}_{2}$ in the Betsiboka estuary decreased from the freshwater end ( $\sim 1050 \mathrm{ppm})$ to values generally between 270 and 725 ppm, with the exception of a high value (1530 ppm) at salinity 14.5 (Fig. 6B). $\mathrm{pCO}_{2}$ values were generally higher in the mangrove creeks (590$3430 \mathrm{ppm})$, with one exceptionally low value (117 ppm) in one of the creeks (note that this data point corresponds to the unusually high $\% \mathrm{O}_{2}$ level of $238 \%$, see above).

The distribution of DIC (Fig. 6C) shows a nearly conservative pattern along the estuarine gradient (with one high value at salinity 14.5), with low DIC concentrations in the freshwater end $\left(0.537 \mathrm{mmol} \mathrm{kg}{ }^{-1}\right)$. For $\delta^{13} \mathrm{C}_{\mathrm{DIC}}$, the conservative mixing scenario was calculated according to (Mook and Tan, 1991):

$\delta^{13} \mathrm{C}=\frac{\operatorname{Sal}\left(\mathrm{DIC}_{\mathrm{F}} \delta^{13} \mathrm{C}_{\mathrm{F}}-\mathrm{DIC}_{\mathrm{M}} \delta^{13} \mathrm{C}_{\mathrm{M}}\right)+\operatorname{Sal}_{\mathrm{F}} \mathrm{DIC}_{\mathrm{M}} \delta^{13} \mathrm{C}_{\mathrm{M}}-\mathrm{Sal}_{\mathrm{M}} \mathrm{DIC}_{\mathrm{F}} \delta^{13} \mathrm{C}_{\mathrm{F}}}{\operatorname{Sal}\left(\mathrm{DIC}_{\mathrm{F}}-\mathrm{DIC}_{\mathrm{M}}\right)+\operatorname{Sal}_{\mathrm{F}} \mathrm{DIC}_{\mathrm{M}}-\operatorname{Sal}_{\mathrm{M}} \mathrm{DIC}_{\mathrm{F}}}$

where Sal is the sample salinity; $\mathrm{DIC}_{\mathrm{F}}, \delta^{13} \mathrm{C}_{\mathrm{F}}$ are the DIC concentration and stable isotope composition at the fresh-

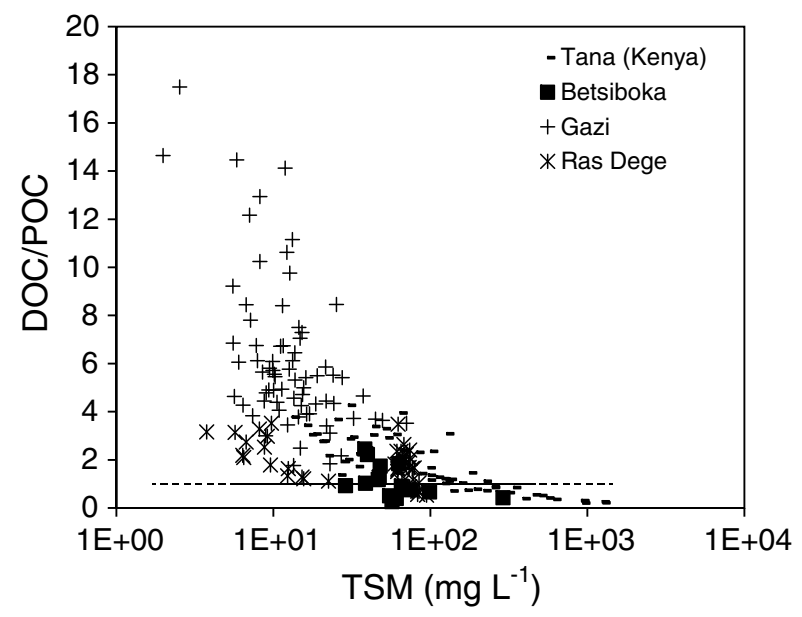

Fig. 3. Plot of DOC/POC ratios versus suspended matter load (TSM) for the Betsiboka (this study) and a number of coastal systems along the east African coast (data from Bouillon et al., 2007a-c).
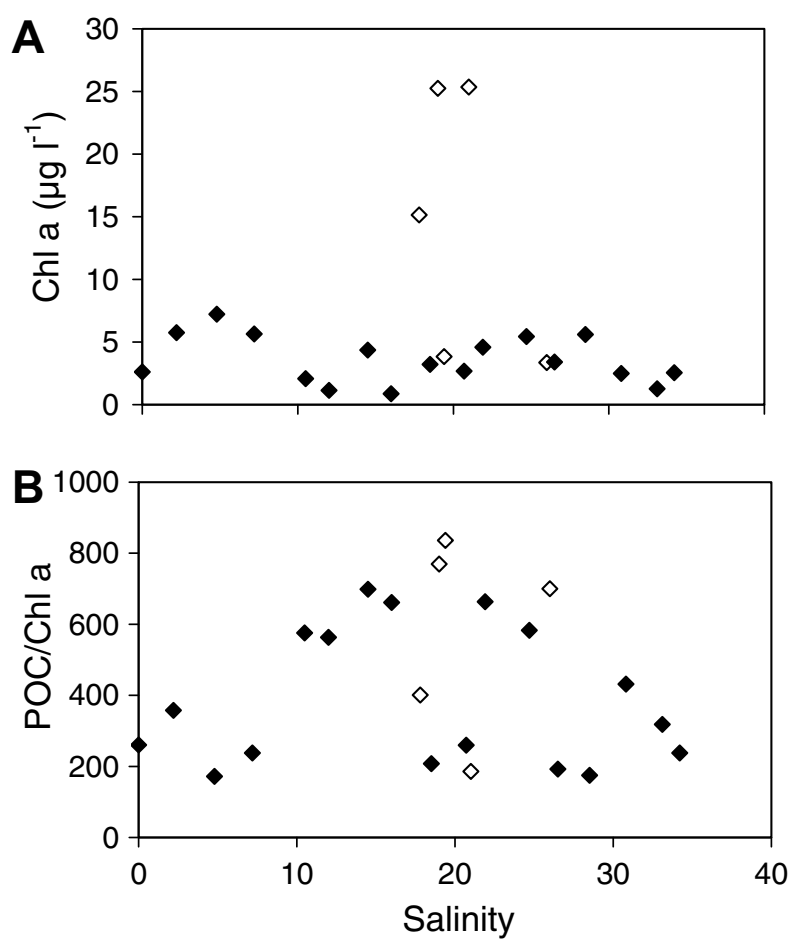

Fig. 4. Distribution of (A) Chl $a$ and (B) POC/Chl $a$ along the Betsiboka estuary (black diamonds) and tidal mangrove creeks (open diamonds).

water or least saline end-member; $\mathrm{DIC}_{\mathrm{M}}, \delta^{13 \mathrm{C}} \mathrm{C}_{\mathrm{M}}$ are the DIC concentration and stable isotope composition at the marine end-member.

The corresponding $\delta^{13} \mathrm{C}_{\mathrm{DIC}}$ gradient deviates only slightly from that expected for conservative mixing (Fig. 6D), ranging between $-5.4 \%$ in the freshwater part to $\sim-0.4 \%$ at salinities $>30$. Similar to what was observed in the $\mathrm{pCO}_{2}$ and DIC data, the samples collected at salinity 14.5 deviated from this pattern, with a much more negative $\delta^{13} C_{\text {DIC }}$ signature of $-6.9 \%$ (Fig. 6D). In the tidal mangrove creeks, DIC is generally similar to or higher than that observed in the estuary for similar salinities (Fig. 6C), with $\delta^{13} \mathrm{C}_{\text {DIC }}$ values consistently lower than at similar salinities in the estuary ( $-12.6 \%$ to $-1.8 \%$, Fig. $6 \mathrm{D})$.

Sediments in the intertidal mangrove forests along the estuary and creeks showed relatively low organic carbon contents (0.5-1.1\%) and TOC/TN ratios (8.4-11.7) (Table 1). $\delta^{13} \mathrm{C}$ signatures of bulk organic carbon $(-19.8 \pm 1.6 \%$, Table 1) were much enriched relative to the dominant mangrove vegetation (with typical values of $\sim-30 \%$ o to $-26 \%$ ), see Fig. 7. All sites showed highest \%OC in the top layers, most pronounced in site 3 where \%OC decreased from 1.10 in the $0-1 \mathrm{~cm}$ section to 0.58 in the $4-10 \mathrm{~cm} \mathrm{sec}-$ tion, accompanied by an increase in $\delta^{13} \mathrm{C}$ from $-23.9 \%$ to $-19.7 \%$. $\delta^{13} \mathrm{C}$ signatures of the bacterial PLFA $\mathrm{i}+\mathrm{a} 15: 0$ $(-24.0 \pm 1.6 \%$, see Table 1 for data per site) were distinctly enriched relative to what would be expected for a dominant reliance on mangrove carbon, assuming a fractionation of $\sim-3.7 \pm 2.1 \%$ between the substrate and $\mathrm{i}+\mathrm{a} 15: 0$, and a global average $\delta^{13} \mathrm{C}$ signature for mangrove litter at $-28.2 \pm 2.1 \%$ o (see Bouillon and Boschker, 2006). $\delta^{13} \mathrm{C}$ signatures of the expected $\mathrm{C}$ substrates correlated well with the bulk sediment organic carbon $\delta^{13} \mathrm{C}$ values (Fig. 8). 


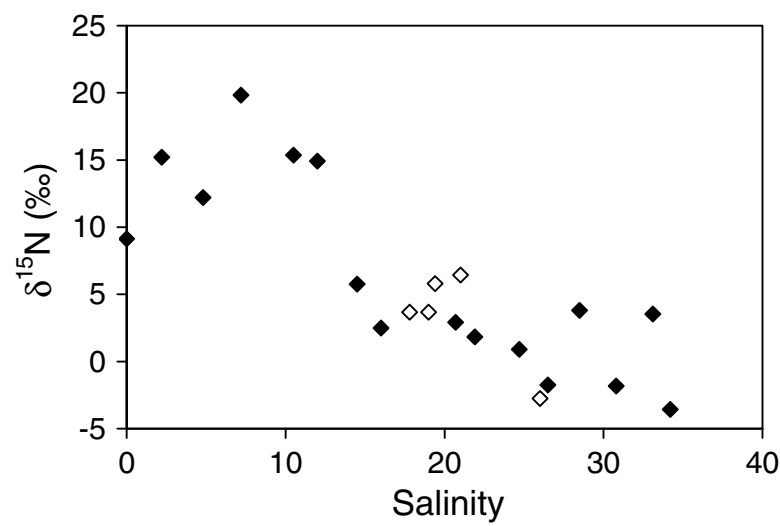

Fig. 5. Distribution of nitrogen stable isotope signatures of particulate $\mathrm{N}$ along the Betsiboka estuary (black diamonds) and tidal mangrove creeks (open diamonds).

\section{Discussion}

The Betsiboka catchment experiences some of the highest reported erosion rates (Randrianarijaona, 1983). In line with this, TSM concentrations were generally high when compared to data from other estuaries and tidal creeks draining into the western Indian Ocean (Fig. 3), although it must be stressed that our sampling campaign was held during the dry season, and that it can be expected that TSM levels could even be much higher during periods of high water flow, when tropical rivers generally exhibit the highest particulate matter load due to runoff and high erosion rates (e.g., Coynel et al., 2005; Hung and Huang, 2005). As has been observed on a wider scale, high TSM levels are generally associated with a relatively low contribution of DOC to the total water column OC pool, i.e., with relatively low DOC/POC ratios (e.g. Ittekkot and Laane, 1991; Abril et al., 2002). This trend is confirmed when comparing the data gathered here with data from estuaries and tidal creeks from the western Indian Ocean region (Fig. 3), and is thought to result from dynamic exchange and repartitioning reactions (see Middelburg and Herman, 2007). DOC/POC ratios for the freshwater end are in line with those predicted by Ludwig et al. (1996b) for rivers opening in the Indian Ocean between $12^{\circ}$ and $16^{\circ} \mathrm{S}$, based on an empirical model. However, while the latter model predicts a DIC:TOC ratio (where TOC is the sum of POC and DOC) of $\sim 0.34$ for this region, our data for the freshwater part indicate a DIC:TOC ratio of 5.0, i.e., almost 15 times higher. Although such a discrepancy may be due to local factors, it should be noted that other field studies in tropical east African estuaries found a similar difference between observed and predicted DIC:TOC ratios (Bouillon et al., 2007a,b).

Table 1

Organic carbon $(\mathrm{OC})$ and total nitrogen (TN) concentrations, elemental ratios (TOC/TN, atom), and $\delta^{13} \mathrm{C}$ signatures of organic carbon and bacteria specific PLFA i + a15:0 in intertidal mangrove sediments in the Betsiboka estuary

\begin{tabular}{lllrll}
\hline Site & \%OC & \%N & \multicolumn{1}{c}{ TOC/TN } & \multicolumn{1}{c}{$\delta^{13} \mathrm{C}-\mathrm{TOC}$} & $\delta^{13} \mathrm{C} \mathrm{i}+\mathrm{a} 15: 0$ \\
\hline 1 & $0.86 \pm 0.03$ & $0.09 \pm 0.00$ & $9.3 \pm 0.5$ & $-19.5 \pm 0.7$ & $-24.4 \pm 1.3$ \\
2 & $0.90 \pm 0.08$ & $0.10 \pm 0.01$ & $9.1 \pm 0.5$ & $-19.1 \pm 0.7$ & $-23.5 \pm 0.6$ \\
3 & $0.83 \pm 0.34$ & $0.07 \pm 0.03$ & $11.0 \pm 0.7$ & $-21.4 \pm 2.4$ & $-26.1 \pm 1.8$ \\
4 & $0.84 \pm 0.06$ & $0.08 \pm 0.01$ & $10.1 \pm 0.8$ & $-18.8 \pm 0.2$ & $-23.4 \pm 0.3$ \\
\hline
\end{tabular}

Values are averages \pm 1 s.d. of 4 different depth sections $(0-1,1-2,2-4$, and $4-10 \mathrm{~cm}$ ), except for site 4 where data for the $0-1 \mathrm{~cm}$ section are missing.
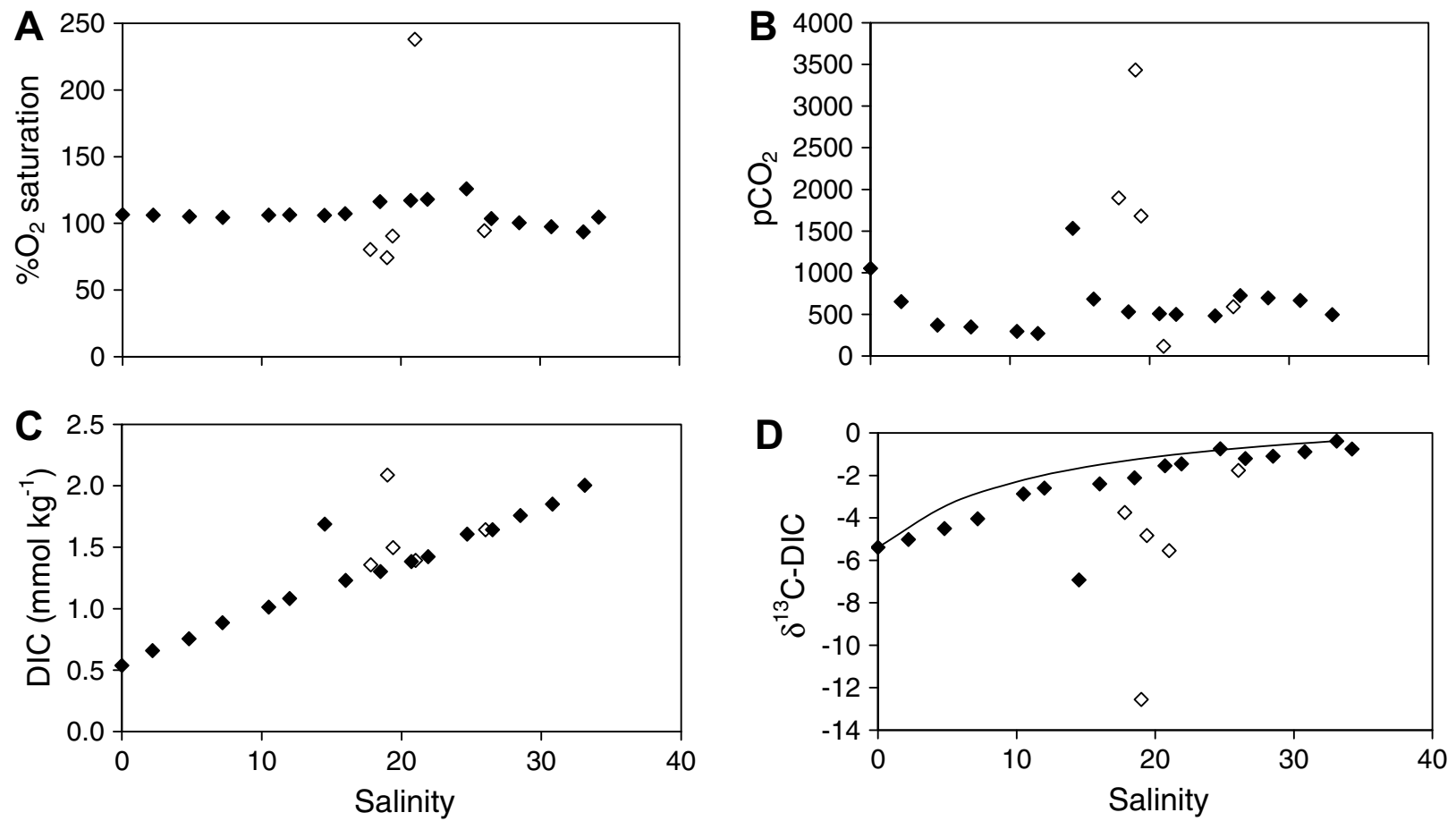

Fig. 6. Profiles of (A) oxygen saturation levels, (B) $\mathrm{pCO}_{2}$, (C) DIC concentrations, and (D) $\delta^{13} \mathrm{C}_{\mathrm{DIC}}$ along the Betsiboka estuary (black diamonds) and tidal mangrove creeks (open diamonds). Line on panel (D) represents the conservative mixing scenario (see text for details). 


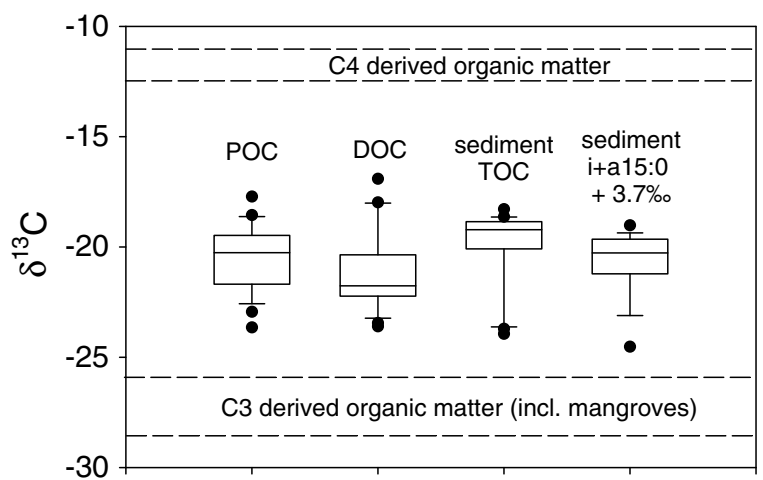

Fig. 7. Summary of $\delta^{13} \mathrm{C}$ data on POC and DOC from the Betsiboka estuary and mangrove creeks, and total organic carbon and bacterial PLFA $\mathrm{i}+\mathrm{a}$ 15:0 from intertidal sediment samples. Data are shown as boxplots; lines represents the median and $75 \%$ interquartile ranges, error bars show the $90 \%$ intervals, and extremes are shown as black circles. For comparison, the typical range of $\delta^{13} \mathrm{C}$ values for $\mathrm{C} 3$ and $\mathrm{C} 4$ derived organic matter are indicated as between dotted lines.

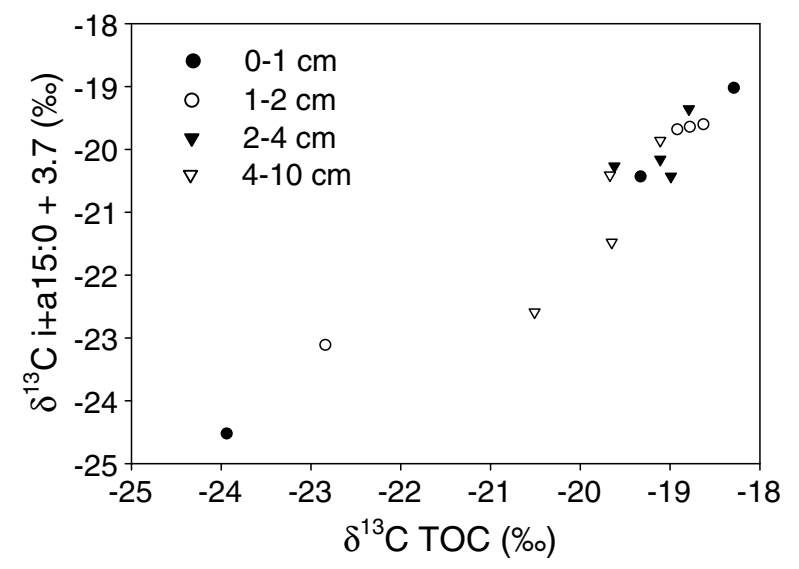

Fig. 8. Plot of $\delta^{13} \mathrm{C}$ signatures of bacterial PLFA ( $\left.\mathrm{i}+\mathrm{a} 15: 0\right)$ versus those of bulk sediment organic carbon in different depth sections of intertidal mangrove sediments from the Betsiboka estuary.

The majority of rivers and estuaries act as net sources of $\mathrm{CO}_{2}$ to the atmosphere (Cole and Caraco, 2001; Borges, 2005; Duarte and Prairie, 2005; Cole et al., 2007). Although the number of data on tropical estuaries is still extremely limited (Borges et al., 2005), some estuaries along the western Indian Ocean were found to have high $\mathrm{pCO}_{2}$, consistent undersaturation in $\mathrm{O}_{2}$, and high resulting $\mathrm{CO}_{2}$ fluxes to the atmosphere (e.g., Bouillon et al., 2007a,b). Similarly, in the freshwater part of tropical rivers consistent $\mathrm{CO}_{2}$ oversaturation and $\mathrm{CO}_{2}$ effluxes have been reported (e.g. see data in Cole and Caraco, 2001; Paquay et al., 2007), and water-atmosphere $\mathrm{CO}_{2}$ fluxes in the Amazon basin have been suggested to represent a quantitatively important component in the overall carbon budget of the basin (Richey et al., 2002).

Our $\mathrm{pCO}_{2}$ data on the Betsiboka, however, do not show very high levels of oversaturation, and are even undersaturated in a few instances (Fig. 6B). This results in an estimated average $\mathrm{CO}_{2}$ efflux $\left(9.1 \pm 14.2 \mathrm{mmol} \mathrm{m}^{-2} \mathrm{~d}^{-1}\right.$, Fig. 9) which is markedly lower than that observed in many other tropical estuaries so far (Sarma et al., 2001;
Bouillon et al., 2007a; Zhai et al., 2007). However, a similar range of $\mathrm{pCO}_{2}$ and low overall $\mathrm{CO}_{2}$ exchange was observed earlier in the subtropical Godavari estuary during a dry season sampling campaign (Bouillon et al., 2003), and it is not unlikely that in both cases, $\mathrm{CO}_{2}$ dynamics might be markedly different during high water periods.

The DIC profile shows near conservative behaviour along the estuarine gradient, with the exception of a single station at salinity 14.5 (Fig. 6C). The latter also coincided with a distinctly higher $\mathrm{pCO}_{2}$ (Fig. 6B) and lower $\delta^{13} \mathrm{C}_{\mathrm{DIC}}$ (Fig. 6D) indicating that this was not due to a measurement artefact. We speculate that the particularly low water column depth at this station $(<0.5 \mathrm{~m})$ could have resulted in disturbance of the sediment-water interface during sampling, and thus may have been influenced by sediment porewater or groundwater inputs enriched in DIC and $\mathrm{pCO}_{2}$ and depleted in $\delta^{13} \mathrm{C}_{\mathrm{DIC}}$ due to respiration. The generally conservative DIC profile is consistent with the overall low $\mathrm{pCO}_{2}$, since mineralization and/or lateral inputs of high DIC water would be expected to lead to a substantial increase in DIC levels along the estuarine gradient (e.g., Bouillon et al., 2007b). The pattern in $\delta^{13} \mathrm{C}_{\mathrm{DIC}}$, however, does indicate that the apparently conservative behaviour of DIC is not absolute, since $\delta^{13} C_{\text {DIC }}$ is slightly lower (by $\sim 1 \%$ at most) than expected for conservative mixing of seawater and freshwater end members, in particular in the mesohaline zone (Fig. 6D). The fact that this excursion is towards lower $\delta^{13} \mathrm{C}$ signatures indicates that this is due to inputs from mineralization, since other potentially influencing factors (outgassing, primary production, and carbonate dissolution) would all be expected to result in more positive $\delta^{13} \mathrm{C}_{\mathrm{DIC}}$ signatures.

\subsection{Sources of organic matter in the Betsiboka estuary}

Based on the data on the global distribution of C3 and C4 vegetation presented in Still et al. (2003), the relative cover of $\mathrm{C} 4$ vegetation in the Betsiboka catchment area was estimated to be $\sim 80-90 \%$. This is consistent with the more detailed vegetation maps presented in Rasambainarivo and Ranaivoarivelo (2003) which show a predominance of non-wooded savannah, and with the dominant grass species mentioned all following the C4 photosynthetic

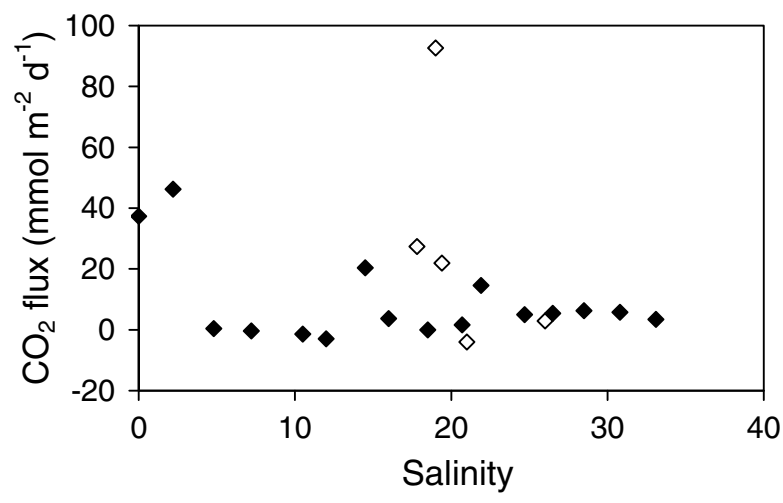

Fig. 9. Estimated $\mathrm{CO}_{2}$ flux between water and atmosphere along the Betsiboka estuary (black diamonds) and tidal mangrove creeks (open diamonds). 
pathway. We had therefore expected that C4-derived organic carbon would dominate the riverine DOC and POC pools, but our $\delta^{13} \mathrm{C}$ data do not confirm this hypothesis. Using end-member values of $-12.8 \%$ and $-28.2 \%$ for $\mathrm{C} 4$ and $\mathrm{C} 3$ derived carbon, respectively (see Bouillon et al., 2007a), the contribution of C4 vegetation to the POC and DOC pool in the freshwater end of the estuary can be estimated at $\sim 35 \%$ and $45 \%$, respectively. Note that these estimates assume that algal inputs (e.g. from within-stream phytoplankton production) can be neglected, which would appear valid considering the relatively low $\mathrm{Chl} a$ levels and high POC/Chl $a$ ratios observed (Fig. $4 \mathrm{~A}$ and B). This much lower input of $\mathrm{C} 4$ derived carbon than expected based on vegetation cover suggests that there is differential mobilization of carbon from C4 vegetated areas and forested areas. Although it has been established that vegetation cover has a major influence on the composition of riverine organic carbon pools, Martinelli et al. (1999) similarly found that the $\delta^{13} \mathrm{C}$ signatures of various size classes of POC in the Piraciciba Basin (Brazil) was more negative than would be expected based on the relative $\mathrm{C} 4$ cover in the basin. The latter authors found the highest $\mathrm{C} 4$ contribution in the fine POC fraction during periods of high water, and suggested that this was caused by high surface runoff from sugarcane and pasture fields during this period. Additionally, Coynel et al. (2005) found that forested sub-basins of the Congo River showed approximately threefold higher area specific fluxes of organic carbon than in savannah dominated basins. Such a mechanism would be consistent with the data of Martinelli et al. (1999) and those presented here, and imply that the relative contribution of C4 inputs to riverine organic carbon pools is consistently less than its relative vegetation cover.

An alternative mechanism to explain the low contribution of C4 material to the aquatic organic carbon pool is differential lability of $\mathrm{C} 3$ and $\mathrm{C} 4$ derived organic matter, i.e., C4 derived organic matter could be preferentially mineralized in the aquatic environment. This was suggested by Mayorga et al. (2005) who found that the $\delta^{13} \mathrm{C}$ signature of respiratory $\mathrm{CO}_{2}$ in rivers in the Amazon basin was considerably enriched in ${ }^{13} \mathrm{C}$ relative to dissolved and particulate organic carbon fractions. For the Mississippi River, in contrast, Bianchi et al. (2004) suggested a stronger association of $\mathrm{C} 4$ derived carbon with fine mineral fractions, which would lead to selective preservation of $\mathrm{C} 4$ derived material. Our data, however, show that at all salinities $<18$, the POC pool was ${ }^{13} \mathrm{C}$ depleted relative to DOC (by on average $\sim 1.7 \%$, see Fig. $2 \mathrm{C}$ and $\mathrm{D}$ ), indicating a more important association of $\mathrm{C} 3$ derived $\mathrm{OC}$ to the particulate pool in the river and upper estuary. Thus, both differences in landscape-level mobilization of organic carbon and differences in lability could contribute to explain the observed contribution of $\mathrm{C} 3$ and $\mathrm{C} 4$ derived organic matter to the riverine organic carbon load.

Differences in $\delta^{13} \mathrm{C}$ signatures of POC and DOC were minor on average, but showed a large variability (Fig. 2C, $\mathrm{D}$, and Fig. 10). At salinity levels $\left\langle 18, \delta^{13} \mathrm{C}_{\mathrm{Doc}}\right.$ values were consistently higher than $\delta^{13} \mathrm{C}_{\mathrm{POC}}$, by up to $4.0 \%$; whereas at higher salinity and in the mangrove creeks, DOC showed $\delta^{13} \mathrm{C}$ signatures consistently ${ }^{13} \mathrm{C}$ depleted relative to POC (by up to $4.4 \%$ o). This confirms recent observations from

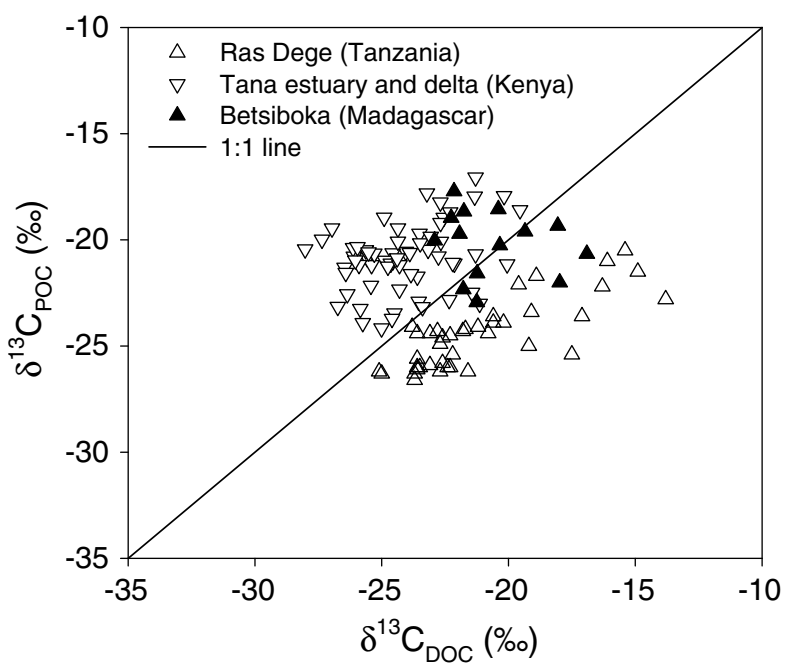

Fig. 10. Comparison of $\delta^{13} \mathrm{C}$ signatures of DOC versus POC for different east African estuaries and coastal ecosystems: Ras Dege (Bouillon et al., 2007c and unpublished), the Tana estuary and delta (Bouillon et al., 2007a), and the Betsiboka estuary (this study).

other (sub)tropical estuarine systems (e.g., see Fig. 10) that dissolved and particulate organic carbon pools may differ significantly in the relative contribution of different organic matter inputs. Very few studies have addressed the mechanisms causing such a different composition of DOC and POC and the changes that these undergo during their transit in the aquatic system, but the advent of more accessible techniques for stable isotope analyses on DOC will no doubt be an important step in generating the data needed to develop further understanding.

In the mesohaline part of the estuary, there were clear net inputs of POC and DOC (Fig. 2A and B), and this coincided with a marked increase in $\delta^{13} \mathrm{C}$ values of both pools (Fig. 2C and D), indicating inputs of ${ }^{13} \mathrm{C}$ enriched organic matter. In view of the presence of a number of small tributaries draining predominantly grasslands, this pattern suggests important inputs of C4 derived organic matter in this part of the estuary. This salinity range also shows higher DOC/POC ratios (1.2-2.5) than in the freshwater part (0.5-0.9), indicating that these lateral inputs provide relatively more DOC than POC. Hence, due to these lateral inputs, the contribution of C4 material to POC and DOC pools was found to be highest in the salinity range 5-12, where it reaches local maxima of $\sim 55 \%$ and $75 \%$, respectively (Fig. 2 C and D).

The observed $\delta^{15} \mathrm{~N}_{\text {PN }}$ profile shows a surprisingly strong gradient in comparison to other tropical estuaries (e.g., Cifuentes et al., 1996; Jennerjahn et al., 2004), with high values of up to $+19.8 \%$ in the mesohaline part of the estuary (Fig. 5). Such mid-estuarine maxima have been reported earlier for a number of temperate estuaries with relatively long residence times and typically with high $\mathrm{NH}_{4}^{+}$levels in their freshwater inflow (see Middelburg and Herman, 2007 and references therein). Such a pattern is thought to be the result of intense $\mathrm{N}$ processing (in particular, nitrification), which leads to a ${ }^{15} \mathrm{~N}$ enriched DIN pool due to preferential removal of 'light' DIN species and hence, higher $\delta^{15} \mathrm{~N}$ values after incorporation of this enriched DIN by microbial communities (e.g., Caraco et al., 1998; de Brabandere et al., 2002). Whether this 
mechanism is also the cause of the observed $\delta^{15} \mathrm{~N}_{\text {PN }}$ profile in the Betsiboka, however, cannot be resolved without either detailed DIN profiles and/or specific $\mathrm{N}$ process rate measurements.

Although our sampling scheme focussed on the main estuary, the limited number of data collected in tidal mangrove creeks point out that they can differ markedly in their biogeochemical signatures when compared to the adjacent estuarine waters. First, although for some of the parameters only a limited amount of data are available, the tidal creeks showed higher POC and DOC concentrations (Fig. 2A and B), with slightly lower $\delta^{13} \mathrm{C}$ signatures (Fig. 2C and D), and most of the creeks also had significantly higher Chl $a$ concentrations (Fig. 4A). Secondly, most of the mangrove creeks showed distinctly lower $\% \mathrm{O}_{2}$ levels, higher $\mathrm{pCO}_{2}$ and DIC and lower $\delta^{13} \mathrm{C}_{\mathrm{DIC}}$ signatures. Such differences have been observed previously in other mangrove systems (e.g. Bouillon et al., 2003, 2007a) and are a result of more intense mineralization, either within the aquatic system or by the interaction with the intertidal area, where benthic mineralization occurring over large areas can result in a typical signature of low $\mathrm{O}_{2}$, high $\mathrm{pCO}_{2}$ and DIC, and low $\delta^{13} \mathrm{C}_{\mathrm{DIC}}$ in the creek waters (Bouillon et al., 2007b). One of the mangrove creeks deviates from this pattern, however, and shows an extremely high $\% \mathrm{O}_{2}$ level (238\%), low $\mathrm{pCO}_{2}$ (117 ppm), and a low POC/Chl $a$ ratio (186). This reflects conditions with high algal biomass and production. Although we have no direct explanation why this creek would differ from others, nutrient inputs from one of the nearby shrimp farms could be responsible.

The data on intertidal sediments below the mangrove canopy show evidence of a high contribution by $\mathrm{C} 4$ derived material, with average $\delta^{13} \mathrm{C}$ signatures per site ranging between $-21.4 \%$ and $-18.8 \%$ (see Table 1 ), which is $7-10 \%$ o more enriched than typical values for mangrove derived organic carbon. Assuming that microphytobenthos and deposited phytoplankton do not contribute extensively, and using end member values of $-28.2 \%$ and $-12.8 \%$ for C3 and C4 derived organic carbon (see Bouillon et al., 2007a), this suggests that C4 derived carbon contributes on average $44-62 \%$ of the sediment TOC pool in these intertidal sediments. Since algal sources are considered to be much more labile than vascular plant derived material, and considering the high turbidity and relatively high POC/ Chl $a$ ratios in the water column (Fig. 2), the exclusion of algal sources is unlikely to significantly bias these estimates. The $\delta^{13} \mathrm{C}$ data on bacterial PLFA clearly follow the variations in bulk sediment $\delta^{13} \mathrm{C}$ (Fig. 8), and when correcting for fractionation effects using an empirically determined average offset of $-3.7 \pm 2.1 \%$ (Bouillon and Boschker, 2006), suggest that bacterial communities show little or no selectivity: $\delta^{13} \mathrm{C}$ signatures estimated for bacteria are only slightly more negative than those found in bulk TOC (Figs. 7 and 8), but given the uncertainty on the fractionation factor used, this falls within the range that can be expected when no selectivity would occur. This implies that riverine suspended matter, with a significant pool of C4 derived organic carbon, is an important source of organic carbon to these intertidal forests. The contribution of $\mathrm{C} 4$ derived carbon to benthic mineralization and bacterial secondary production in these systems is consistent with our earlier observations in a northern Kenyan delta with C4 inputs (Bouillon et al., 2007a). In the latter study, porewater DOC was found to be predominantly of mangrove (i.e., C3) origin, but unfortunately, comparative data from our Betsiboka estuary sediments are not available.

In summary, this first report on the biogeochemistry of a Malagasy estuary demonstrated that the organic carbon load consists of a mixture of $\mathrm{C} 3$ and $\mathrm{C} 4$ derived organic matter, with a markedly smaller contribution of $\mathrm{C} 4$ derived carbon than would be expected based on the relative vegetation cover in the catchment area. Nevertheless, sedimentation of this C4 derived organic matter in the intertidal mangrove areas in the estuary resulted in a significant contribution of terrestrial C4 carbon to bacterial mineralization in these sediments. At least during the dry season, the Betsiboka estuary was a relatively minor source of $\mathrm{CO}_{2}$ to the atmosphere.

\section{Acknowledgements}

This work was supported by the Research Foundation Flanders (FWO-Vlaanderen, contracts G.0632.06, G.0395.07, and 1.5.070.05). S.B. was supported by a postdoctoral mandate by the FWO-Vlaanderen, and A.V.B. is a research associate at the FNRS (Fonds de la Recherche Scientifique). We thank D.P. Gillikin for useful suggestions on a draft of this manuscript, and E. Krull and an anonymous referee who provided constructive comments to an earlier version of this paper. This is publication 4246 of the Netherlands Institute of Ecology (NIOO-KNAW).

\section{References}

Abril, G., Nogueira, M., Etcheber, H., Cabeçadas, G., Lemaire, E., Brogueira, M.J., 2002. Behaviour of organic carbon in nine contrasting European estuaries. Estuarine Coastal and Shelf Science 54, 241-262.

Aufdenkampe, A.K., Hedges, J.I., Richey, J.E., Krusche, A.V., Llerena, C.A., 2001. Sorptive fractionation of dissolved organic nitrogen and amino acids onto fine sediments within the Amazon Basin. Limnology and Oceanography 46, 1921-1935.

Aufdenkampe, A.K., Mayorga, E., Hedges, J.I., Llerena, C., Quay, P.D., Gudeman, J., Krusche, A.V., Richey, J.E., 2007. Organic matter in the Peruvian headwaters of the Amazon: compositional evolution from the Andes to the lowland Amazon mainstem. Organic Geochemistry 38, 337-364.

Bernardes, M.C., Martinelli, L.A., Krusche, A.V., Gudeman, J., Moreira, M., Victoria, R.L., Ometto, J.P.H.B., Ballester, M.V.R., Aufdenkampe, A.K., Richey, J.E., Hedges, J.I., 2004. Riverine organic matter composition as a function of land use changes, southwest Amazon. Ecological Applications 14, S263-S279.

Berthois, L., Crosnier, A., 1965. La sédimentation dans l'estuaire de la Betsiboka (côte Ouest de Madagascar) et sur le plateau continental au large de l'estuaire. Sédimentologie. Comptes Rendues de l'Academie de Sciences Paris 261, 3647-3649.

Bianchi, T.S., Filley, T., Dria, K., Hatcher, P.G., 2004. Temporal variability in sources of dissolved organic carbon in the lower Mississippi River. Geochimica et Cosmochimica Acta 68, 959-967.

Bird, M.I., Giresse, P., Chivas, A.R., 1994. Effect of forest and savanna vegetation on the carbon isotope composition of sediments from the Sanaga River, Cameroon. Limnology and Oceanography 39, 18451854.

Borges, A.V., 2005. Do we have enough pieces of the jigsaw to integrate $\mathrm{CO}_{2}$ fluxes in the Coastal Ocean? Estuaries 28, 3-27.

Borges, A.V., Delille, B., Frankignoulle, M., 2005. Budgetting sinks and sources of $\mathrm{CO}_{2}$ in the coastal ocean: diversity of ecosystems counts. Geophysical Research Letters 32, L14601. doi:10.1029/2005GL02305.

Bouillon, S., Boschker, H.T.S., 2006. Bacterial carbon sources in coastal sediments: a cross-system analysis based on stable isotope data of biomarkers. Biogeosciences 3, 175-185. 
Bouillon, S., Frankignoulle, M., Dehairs, F., Velimirov, B., Eiler, A., Etcheber, H., Abril, G., Borges, A.V., 2003. Inorganic and organic carbon biogeochemistry in the Gautami Godavari estuary (Andhra Pradesh, India) during pre-monsoon: the local impact of extensive mangrove forests. Global Biogeochemical Cycles 17 (4), 1114. doi:10.1029/ 2002GB00202.

Bouillon, S., Korntheuer, M., Baeyens, W., Dehairs, F., 2006. A new automated setup for stable isotope analysis of dissolved organic carbon. Limnology and Oceanography: Methods 4, 216-226.

Bouillon, S., Dehairs, F., Schiettecatte, L.-S., Borges, A.V., 2007a. Biogeochemistry of the Tana estuary and delta (northern Kenya). Limnology and Oceanography 52, 46-59.

Bouillon, S., Dehairs, F., Velimirov, B., Abril, G., Borges, A.V., 2007b. Dynamics of organic and inorganic carbon across contiguous mangrove and seagrass systems (Gazi Bay, Kenya). Journal of Geophysical Research 112, G02018. doi:10.1029/2006JG00032.

Bouillon, S., Middelburg, J.J., Dehairs, F., Borges, A.V., Abril, G., Flindt, M., Ulomi, S., Kristensen, E., 2007c. Importance of intertidal sediment processes and porewater exchange on the water column biogeochemistry in a pristine mangrove creek (Ras Dege, Tanzania). Biogeosciences 4, 311-322.

Caraco, N.F., Lampman, G., Cole, J.J., Limburg, K.E., Pace, M.L., Fisher, D., 1998. Microbial assimilation of DIN in a nitrogen rich estuary: implications for food quality and isotope studies. Marine Ecology Progress Series 167, 59-71.

Cifuentes, L.A., Coffin, R.B., Solorzano, L., Cardenas, W., Espinoza, J., Twilley, R.R., 1996. Isotopic and elemental variations of carbon and nitrogen in a mangrove estuary. Estuarine, Coastal and Shelf Science 43, 781-800

Cole, J.J., Caraco, N.F., 2001. Carbon in catchments: connecting terrestrial carbon losses with aquatic metabolism. Marine and Freshwater Research 52, 101-110.

Cole, J.J., Praire, Y.T., Caraco, N.F., McDowell, W.H., Tranvik, L.J., Striegl, R.G., Duarte, C.M., Kortelainen, P., Downing, J.A., Middelburg, J.J., Melack, J., 2007. Plumbing the global carbon cycle: integrating inland waters into the terrestrial carbon budget. Ecosystems 10, 171-184.

Coynel, A., Seyler, P., Etcheber, H., Meybeck, M., Orange, D., 2005. Spatial and seasonal dynamics of total suspended sediment and organic carbon species in the Congo River. Global Biogeochemical Cycles 19, GB4019. doi:10.1029/2004GB00233.

De Brabandere, L., Dehairs, F., Van Damme, S., Brion, N., Meire, P., Daro, N., 2002. $\delta^{15} \mathrm{~N}$ and $\delta^{13} \mathrm{C}$ dynamics of suspended organic matter in freshwater and brackish waters of the Scheldt estuary. Journal of Sea Research 48, 1-15.

Duarte, C.M., Prairie, Y.T., 2005. Prevalence of heterotrophy and atmospheric $\mathrm{CO}_{2}$ emissions from aquatic ecosystems. Ecosystems 8, 862-870.

Frankignoulle, M., Borges, A.V., 2001. Direct and indirect pCO2 measurements in a wide range of $\mathrm{pCO} 2$ and salinity values (the Scheldt estuary). Aquatic Geochemistry 7, 267-273.

Gillikin, D.P., Bouillon, S., 2007. Determination of $\delta^{18} \mathrm{O}$ of water and $\delta^{13} \mathrm{C}$ of dissolved inorganic carbon using a simple modification of an elemental analyzer - isotope ratio mass spectrometer (EA-IRMS): an evaluation. Rapid Communications in Mass Spectrometry 21, 14751478.

Hung, J.J., Huang, M.H., 2005. Seasonal variations of organic carbon and nutrient transport through a tropical estuary (Tsengwen) in southwestern Taiwan. Environmental Geochemistry and Health 27, 75-95.

Ittekkot, V., Laane, R.W.P.M., 1991. Fate of riverine particulate organic matter. In: Degens, E.T., Kempe, S., Richey, J.E. (Eds.), Biogeochemistry of Major World Rivers. Wiley, UK. 466pp.

Jennerjahn, T.C., Ittekkot, V., Klöpper, S., Adi, S., Nugroho, S.P., Sudiana, N., Yusmal, A., Gaye-Haake, B., 2004. Biogeochemistry of a tropical river affected by human activities in its catchment: Brantas River estuary and coastal waters of Madura Strait, Java, Indonesia. Estuarine, Coastal and Shelf Science 60, 503-514.

Kaplan, L.A., 1994. A field and laboratory procedure to collect, process, and preserve freshwater samples for dissolved organic carbon analysis. Limnology and Oceanography 39, 1470-1476.

Klein, J., 2002. Deforestation in the Madagascar Highlands - established 'truth' and scientific uncertainty. Geographical Journal 56, 191-199.
Lebigre, J.M., 1990. Les marais maritimes de Gabon et de Madagascar. Contribution à l'étude d'un milieu tropical. PhD thesis, Institut de Géographie, Université de Bordeaux III, 988pp.

Liss, P.S., Slater, P.G., 1974. Flux of gases across the air-sea interface. Nature 247, 181-184.

Ludwig, W., Probst, J.L., Kempe, S., 1996a. Predicting the oceanic input of organic carbon by continental erosion. Global Biogeochemical Cycles $10,23-41$

Ludwig, W., Amiotte-Suchet, P., Probst, J.L., 1996b. River discharges of carbon to the world's oceans: determining local inputs of alkalinity and of dissolved and particulate organic carbon. Comptes Rendues de l'Academie de Sciences Paris II 323, 1007-1014.

Lyons, W.B., Nezat, C.A., Carey, A.E., Hicks, D.M., 2002. Organic carbon flux to the ocean from high-standing islands. Geology 30, 443-446.

Martinelli, L.A., Ballester, M.V., Krusche, A.V., Victoria, R.L., de Camargo, P.B., Bernardes, M., Ometto, J.P.H.B., 1999. Landcover changes and $\delta^{13} \mathrm{C}$ composition of riverine particulate organic matter in the Piracicaba river basin (southeast region of Brazil). Limnology and Oceanography 44, 1826-1833.

Mayorga, E., Aufdenkampe, A.K., Masiello, C.A., Krusche, A.V., Hedges, J.I., Quay, P.D., Richey, J.E., Brown, T.A., 2005. Young organic matter as a source of carbon dioxide outgassing from Amazonian rivers. Nature 436, 538-541.

Middelburg, J.J., Herman, P.J.M., 2007. Organic matter processing in tidal estuaries. Marine Chemistry 106, 127-147.

Milliman, J.D., 1995. Sediment discharge to the Ocean from small mountainous rivers: the New Guinea example. Geo-Marine Letters $15,127-133$.

Mook, W.G., Tan, T.C., 1991. Stable carbon isotopes in rivers and estuaries. In: Degens, E.T., Kempe, S., Richey, J.E. (Eds.), Biogeochemistry of Major World Rivers, SCOPE. Wiley. p. 245-264.

Paquay, F.S., Mackenzie, F.T., Borges, A.V., 2007. Carbon dioxide dynamics in rivers and coastal waters of the "Big Island" of Hawaii, USA, during baseline and heavy rain conditions. Aquatic Geochemistry 13,1-18.

Paulian, R., 1984. Madagascar: a microcontinent between Africa and Asia. In: Jolly, A., Oberlé, P., Albignac, R. (Eds.), Key Environments: Madagascar. Pergamon Press, Oxford, pp. 1-2.

Randrianarijaona, P., 1983. The erosion of Madagascar. Ambio 12,308-311.

Rasambainarivo, J.H., Ranaivoarivelo, N., 2003. Grassland and Pasture Crop Systems: Madagascar. FAO (Food and Agriculture Organization).

Raymond, P.A., Cole, J.J., 2001. Gas exchange in rivers and estuaries: choosing a gas transfer velocity. Estuaries 24, 312-317.

Richey, J.E., Melack, J.M., Aufdenkampe, A.K., Ballester, M.V., Hess, L.L. 2002. Outgassing from Amazonian rivers and wetlands as a large tropical source of atmospheric $\mathrm{CO}_{2}$. Nature 416, 617-620.

Ritter, D.F., 1986. Process Geomorphology. Wm. C. Brown Pubs., Dubuque.

Sarma, V.V.V.S., Kumar, M.D., Marerikar, M., 2001. Emission of carbon dioxide from a tropical estuarine system, Goa, India. Geophysical Research Letters 28, 1239-1242.

Schlünz, B., Schneider, R.R., 2000. Transport of terrestrial organic carbon to the oceans by rivers: re-estimating flux- and burial rates. International Journal of Earth Sciences 88, 599-606.

Sharp, J.H., Carlson, C.A., Peltzer, E.T., Castle-Ward, D.M., Savidge, K.B. Rinker, K.R., 2002. Final dissolved organic carbon broad community intercalibration and preliminary use of DOC reference materials. Marine Chemistry 77, 239-253.

Still, C.J., Berry, J.A., Collatz, G.J., DeFries, R.S., 2003. Global distribution of C3 and C4 vegetation: carbon cycle implications. Global Biogeochemical Cycles 17 (1), 1006. doi:10.1029/2001GB00180.

Vägen, T.-G., Walsh, M.G., Shepherd, K.D., 2007. Stable isotopes for characterisation of trends in soil carbon following deforestation and land use change in the highlands of Madagascar. Geoderma 135, 133-139.

Vanden Bossche, J.-P., Bernacsek, G.M., 1990. Source book for the inland fishery resources of Africa: 1. CIFA Technical Paper No. 18.1, Rome, FAO, 240pp.

Vorosmarty, C.J., Fekete, B.M., Tucker, B.A., 1998. Global RiverDischarge, 1807-1991, V. 1.1 (RivDIS). Data set, available on-line from Oak Ridge National Laboratory Distributed Active Archive Center, Oak Ridge, Tennessee, USA. <http://www.daac.ornl.gov>

Zhai, W., Dai, M., Guo, X., 2007. Carbonate system and CO2 degassing fluxes in the inner estuary of Changjiang (Yangtze) river, China. Marine Chemistry 107, 342-356. 